\title{
Effects of Seed Pre-Treatments on Germination of Kapok Tree Ceiba petandra (l.) Gaertn. in Northern Savannah of Nigeria: A Case Study of Kaduna State, Nigeria
}

\author{
*Corresponding Author \\ Sodimu Akintunde Isiaka \\ Article History \\ Received: 09.06.2020 \\ Accepted: 16.06 .2020 \\ Published: 25.06.2020
}

Sodimu Akintunde Isiaka*

Federal College of Forestry Mechanization, Forestry Research Institute of Nigeria, PMB 2273, Afaka-Kaduna, Nigeria

\begin{abstract}
Effects of seed pre-treatments on germination of Ceiba petandra (Kapok) tree in Northern Savanna of Nigeria were studied, using Kaduna State as a case study. Three (3) pre-treatments methods (concentrated Sulphuric acid $\left(\mathrm{H}_{2} \mathrm{SO}_{4}\right)$ scarification, cold water and mechanical scarification) were used in Complete Randomized Design (CRD) experiments. The seeds were soaked in water for the period ranging between 1-7 days; those soaked in conc. Sulphuric acid were for the period ranging from 5minutes to 35minutes, while mechanical scarification ranged from 5-35 minutes. The data collected were analyzed using ANOVA and then subjected to Duncan Multiple Range Test (DMRT). The results revealed that treatment with cold water immersion for 2days gives $95 \%$ germination while treatment for $6 \mathrm{days}$ and 7 days are significantly $(\mathrm{P}<0.05)$ lower in germination, $45 \%$ and $30 \%$ respectively. Acid scarification shows that the treatment with conc. $\mathrm{H}_{2} \mathrm{SO}_{4}$ for 20 minutes resulted in $85 \%$ germination while treatment for 5 minutes and 10 minutes were significantly $(\mathrm{P}<0.05)$ lower with germination of $41 \%$ and $45 \%$ respectively. However, for mechanical scarification the result shows that germination percentage improved with increased period of shaken. Germination of seeds shook for 25 minutes, 30 minutes and 35 minutes were the highest and were not significantly $(\mathrm{P}<0.05)$ different from each other $(80 \%, 71 \%$ and $68 \%)$. It is therefore, recommended that, for uniform germination and improvement of growth of Ceiba petandra the nursery workers should make use of cold water immersion by soaking the seeds in it for 2 days.
\end{abstract}

Keywords: Pre-treatment, Germination, Northern Savannah, Kapok.

\section{INTRODUCTION}

Ceiba pentandra (L.) Gaertn is commonly known as Kapok tree of silk cotton trees. It is a tropical tree of the order Malvales and the family malvaceae which was previously separated from the family Bombacaceae [1]. Ceiba pentandra is a fast growing indigenous tree species to West Africa and also found in South America [2, 3]. Kapok Tree or Ceiba pentandra is now a widely cultivated in Southeast Asia for its seed fibre. It is fast growing and reaches up to 70 $\mathrm{m}$ in height and $3 \mathrm{~m}$ in trunk diameter. The trunk is buttressed and large simple thorns, similar to that of on many of the larger branches, are found on it. The crown is thin and pagoda shaped. The leaves are palmate, with 5 to 9 leaflets each. Kapok produces several pods that contain seeds covered by fibre. Kapok fibre is yellowish in colour, light, very buoyant, water resistant, resilient, but very flammable. The seed of kapok yields oil that is used in making soap and as fertilizer. The seed is edible either raw or cooked (roasted and ground into powder) [4]. It is an emergent tropical forest tree species that can grow up to about height. The wood is very light and is used for preparation of plywood [5], packaging, lumber, light construction, pulp and paper products, match splint, canoes, veneer, block boards, furniture, boxes and aircraft modeling [6].

The fruit is collected for the valuable kapok floss and used for stuffing pillows, mattresses, cushions, life jackets, lifeboats, insulating [7]. The seed contains 20-25 percent nondrying oil, used as a lubricant and in soap manufacturing [8]. Ceiba pentandra is known to be an excellent source of nutrient such as minerals, vitamins and very high moisture content of 60 to $83 \mathrm{~g} / 100 \mathrm{~g}$ [9]. The young leaf of Ceiba pentandra is extremely high in fibre content [10].

Copyright @ 2020: This is an open-access article distributed under the terms of the Creative Commons Attribution license which permits unrestricted use, distribution, and reproduction in any medium for non commercial use (NonCommercial, or CC-BY-NC) provided the original author and source are credited. 
Soluble dietary fibres have health-promoting properties as they have been implicated in the lowering of plasma and liver cholesterol concentrations [11]. The high value of carbohydrate and protein suggest that the nutritional quality of the Ceiba pentandra leaf is high and this may be a veritable tool for body nourishment [12]. In Nigeria, the leaves are used as an alternative laxative and the infusion is given as a cure for colic in man and in livestock [13]. The young leaves are sometimes cooked and eaten in West Africa as a soup herb [14]. The seeds of $C$. pentandra provide important food resources to small mammalian wildlife (rodents), and it is an important source of local human medicines in curing and prevention of various diseases [15]. Apparently, the species provides important roosting sites for some mammalian species (bats), insects and pollinator bees as well as several bird species [16]. However, temperature has been observed to strongly influence seed germination of tropical forest trees, including $C$. pentandra [17]. It is worth noting that the conditions leading to the germination of seeds may be complex given that several factors including environmental (e.g. temperature, water), seed attributes e.g. size, weight and shape [18], physiological [19] and seed predation [20] singly or together may affect seed viability and subsequent seed germination ability.

Seed pre-treatments have been used to describe ways of treating seeds to increase their vigor for germination. In view of the potentials of Ceiba pentandra, its germination and growth rate without seed pretreatment is very slow. Sometimes seeds of Ceiba pentandra may fail to germinate under favorable environmental conditions and are therefore said to exhibit some degree of dormancy. Due to excessive temperature around Guinea Savannah Zone (Northern and Southern), Ceiba petandra seeds get damaged before the pods naturally dehiscent. This study therefore, is to investigate suitable seed pre-treatment methods in the nursery to ensure rapid and uniform germination of high quality seedlings of Ceiba petandra for plantation establishment and economic uses.

\section{Materials ANd Methods MATERIALS}

The materials used for this research are: Ceiba petandra seeds, chemical $\left(\mathrm{H}_{2} \mathrm{SO}_{4}\right)$, water, and coarse sand.

\section{Study Area}

The experiment was carried out at the Green house of Federal College of Forestry Mechanization Afaka, located at Latitude $10^{0} 37^{\prime} \mathrm{N}$ and Longitude $7^{0} 17^{\prime} \mathrm{N}$ [21].

\section{Seed Collection and Processing}

The Ceiba petandra. seed used for this study were collected randomly from matured plus trees sparsely distributed in FRIN research plots at Buruku Forest Reserve in Chikun local Government Area of Kaduna State. The pods were collected directly by plucking and hand picking under the trees. The trees were of timber sizes and of good phenotypically. Wildlings were hardly seen around the plantation area. The pod (fruits) was crushed manually to extract the seeds. The seeds were embedded in the silk cotton and extracted by shaking or hand picking individual seed. The seeds were tiny but visible and each pod contains about 180 seeds on the average. Apparently, viable seed of Ceiba petandra. were determined using floatation method in which viable seed sank to bottom.

\section{Experimental Design}

Three (3) treatments at seven (7) levels each with single level control (water, Acid, Mechanical and Control) were used, making a total of twenty-two (22) treatments. The seedlings were arranged in a Completely Randomized Design (CRD) with four (4) replicates

\section{Germination Percentage}

Germination percentage was derived as the ratio of seedlings germinated to the total number of seeds planted multiplied by 100 .

$$
\text { Germination } \%=\underline{\text { Number of Seeds Germinated } \times 100}
$$

Total Number of Seeds Planted

\section{Experimental Procedure \\ Water Treatment}

Viable seeds are soaked in ordinary water under room temperature for various time periods (treatment) ranging from 1day to 7 days with a control of 0 day (not soaked in water). 60 seeds were used and 4 replicated for each period of treatment. 240 seeds were used for each treatment, which makes the total of 1,920 for eight (8) treatment.

\section{Acid Treatment}

For acid treatment, concentrated $\mathrm{H}_{2} \mathrm{SO}_{4}$ was used to soak viable seeds ranging from $0,5,10,20,25,30$, and 35 minutes respectively. Each of the soaked time constitute the treatment in which 60 seeds were tested and replicated 4 times. 240 seeds were used and total of 1,920 seed for the acid treatment. 


\section{Mechanical Scarification}

In mechanical scarification, viable seeds coat was weakening using coarse sand, which were enclosed in a container with the seed. It was shaken for periods of time varying from $0,5,10,15,20,25,30,35$ and 40 minutes. Each of the shaking time periods constitute treatment. 60 seeds were used and replicated 4 times, which gives the total of 1,920 seeds for 8 treatments.

\section{Statistical Analysis}

All data collected were subjected to analysis of variance (ANOVA) and Duncan multiple range test contrasts $(\mathrm{p}<0.05)$.

\section{RESULTS AND DiSCUSSION \\ Cold Water Treatment}

The results of the effect of seeds of Ceiba petandra. soaked in cold water are given in Table-1. Germination percentage improved with increase period of seed soaking in cold water up to 2 days, after which there was gradual decline in the germination. Germination percentage seeds soaked for 2 days is the highest and its statistically $(\mathrm{P}<0.05)$ having equal value with1day, 3days and 4 days. However, treatment with cold water for days resulted in $95 \%$ germination while for 5 days, 6 days and 7 days gave significantly $(\mathrm{P}<0.05)$ low germination of 55\%, 45\% and 30\% respectively. Seed soaking in cold water has been used by lot of workers to break dormancy in seeds [22-24]. However, the results of the cold water pre-treatment are in agreement with that of Ibrahim and Otegbeye [25] who reported that prolong soaking of $A$. digitata seeds in cold water resulted in increasing rate of seed germination. Ojo, M.O [7] also observed that cold water pre-treatment of Ceiba petandra enhance its rate of germination. The relatively lower germination recorded for seeds soaked in cold water for 6 days (45\%) and 7days (30\%) shows that the seeds might have been over stayed in water thus, result in spoilage of some of the seeds.

\section{Acid Treatment}

Table-2 revealed the effect of concentrated $\mathrm{H}_{2} \mathrm{SO}_{4}$ on seed germination of Ceiba petendra improved with increased period of seed soaking in the acid up to 20 minutes, after which there was gradual declination in the germination percentages of seeds soaked for 25 minutes, 30 minutes and 35 minutes respectively. Seed soaked for 20 minutes were the highest and were not significantly $(\mathrm{P}<0.05)$ different from one another. Treatment with conc. $\mathrm{H}_{2} \mathrm{SO}_{4}$ for 20 minutes resulted in $85 \%$ germination while treatment for 5 minutes and 10 minutes were significantly $(\mathrm{P}<0.05)$ lower with germination of $41 \%$ and $45 \%$ respectively. However, acid scarification has been used by lots of workers to break dormancy in seeds [26-29]. Ailero, B. L [30] found conc. sulphuric acid to be very effective in breaking seed coat dormancy in Terminalia superba and Parkia biglobosa respectively [31,32] also showed that germination of Acacia albida, A. Senegal, A. nilotica treated with conc. Sulphuric acid for 10minutes for A. albida, A. Senegal and 60 minutes for A. nilotica; significantly gave better germination $(99 \%, 57.3 \%$ and $90 \%$ respectively, than other treatment). Therefore, the results obtained is in consonant with all the above workers.

\section{Mechanical Scarification}

Table-3 revealed the effect of mechanical scarification on seed of A. digitata. Germination percentage improved with increased period of shaken in the mechanical scarification up to 25 minutes, after which there was gradual decline in the germination. Germination percentage of seeds shaken for 25 minutes, 30 minutes and 35 minutes were the highest and were not significantly $(\mathrm{P}<0.05)$ different from each other. The results above are in agreement with $[33,30,25]$.

Table-1: Effect of Increased Duration (days) in Cold Water on Germination of Ceiba petandra Seeds

\begin{tabular}{|l|l|l|}
\hline S/No & Variable/Treatment & $*$ Mean \\
\hline a. & control & $15 \mathrm{a}$ \\
\hline b. & Seed soaked for 1 day & $33 \mathrm{~b}$ \\
\hline c. & Seed soaked for 2 days & $95 \mathrm{c}$ \\
\hline d. & Seed soaked for 3 days & $75 \mathrm{c}$ \\
\hline e. & Seed soaked for 4 days & $70 \mathrm{c}$ \\
\hline f. & Seed soaked for 5 days & 50d \\
\hline g. & Seed soaked for 6 days & $45 \mathrm{~d}$ \\
\hline h. & Seed soaked for 7 days & $30 \mathrm{~d}$ \\
\hline
\end{tabular}

DMRT: Figures with the same letters are statistically equal values $(\mathrm{P}<0.05)$ 
Table-2: Effect of Increased Duration (minutes) in Concentrated Sulphuric Acid $\left(\mathrm{H}_{2} \mathrm{SO}_{4}\right)$ on Germination of $\mathrm{Ceiba}$ petandra

\begin{tabular}{|l|l|l|}
\hline S/No & Variable/Treatment & $*$ Mean \\
\hline a. & control & $15 \mathrm{a}$ \\
\hline b. & Seed soaked in conc. $\mathrm{H}_{2} \mathrm{SO}_{4}$ for 5 minutes & $41 \mathrm{~b}$ \\
\hline c. & Seed soaked in conc. $\mathrm{H}_{2} \mathrm{SO}_{4}$ for 10 minutes & $45 \mathrm{c}$ \\
\hline d. & Seed soaked in conc. $\mathrm{H}_{2} \mathrm{SO}_{4}$ for 15 minutes & $53 \mathrm{c}$ \\
\hline e. & Seed soaked in conc. $\mathrm{H}_{2} \mathrm{SO}_{4}$ for 20 minutes & $85 \mathrm{~d}$ \\
\hline f. & Seed soaked in conc. $\mathrm{H}_{2} \mathrm{SO}_{4}$ for 25 minutes & $70 \mathrm{~d}$ \\
\hline g. & Seed soaked in conc. $\mathrm{H}_{2} \mathrm{SO}_{4}$ for 30 minutes & $65 \mathrm{~d}$ \\
\hline h. & Seed soaked in conc. $\mathrm{H}_{2} \mathrm{SO}_{4}$ for 35 minutes & $48 \mathrm{e}$ \\
\hline
\end{tabular}

DMRT: Figures with the same letters are statistically equal value $(\mathrm{P}<0.05)$

Table-3: Effect of Increased Duration (Minutes) in Mechanical Scarification on Germination of Ceiba petandra

\begin{tabular}{|l|l|l|}
\hline S/No & Variable/Treatment & $*$ Mean \\
\hline a. & control & $15 \mathrm{a}$ \\
\hline b. & Seed shaken for 5 minutes & $32 \mathrm{~b}$ \\
\hline c. & Seed shaken for 10 minutes & $45 \mathrm{c}$ \\
\hline d. & Seed shaken for 15 minutes & $47 \mathrm{c}$ \\
\hline e. & Seed shaken for 20 minutes & $49 \mathrm{~d}$ \\
\hline f. & Seed shaken for 25 minutes & $80 \mathrm{~d}$ \\
\hline g. & Seed shaken for 30 minutes & $68 \mathrm{~d}$ \\
\hline h. & Seed shaken for 35 minutes & $62 \mathrm{~d}$ \\
\hline
\end{tabular}

DMRT: Figures with the same letters are statistically equal value $(\mathrm{P}<0.05)$

\section{Conclusion ANd RECOMMENDATION \\ Conclusion}

Pre-germination treatments are needed to break physical dormancy caused by hard seed coats or pericarps. The cause and nature of seed coat impermeability are not fully understood. However, it was observed that out of all the three (3) pre-treatments methods applied (Acid; Mechanical and Coldwater), the best germination of over 95\% was achieved with soaking the seeds in water for 2 days.

\section{Recommendation}

Based on the above results it was recommended that for uniform germination and improvement of growth of Ceiba petandra, the nursery workers should make use of ordinary water immersion by soaking the seeds in it for 2 days.

\section{REFERENCES}

1. Sofomora, L. A. (1993). Medical Plants and Traditional Medicine in Africa. Spectrum Books Ltd, Ibadan, 3: 69-71.

2. Baker, H. G. (1965). The evolution of the cultivated kapok tree: a probable West African. Oxford University Press, United Kingdom. 45-56.

3. FPIB. (1994). Timber Species Classification and Assessment of Exploration Patterns. Forest inventory and management project. 67:55-60. FD Planning branch, Kumasi, FIMP.

4. Plants for a Future. (2012). Ceiba pentandra (L) Gaertn accessed @ https://pfaf.org/USER/Plant.aspx?LatinName=Ceiba+pentandra on 02/04/2020

5. Attah, A. (2005). Africa's Production and Trade of TP, Present Status and Outlook. Paper Presented at the ITTO/FAO International Conference on Tropical Plywood, 1 2:261-263 September 2005, Beijing, China.

6. Sahid, M., \& Zeven, A. C. (2003). Ceiba pentandra (L.) Gaertn. In: Brink, M., \& Escobin, R. P. (Editors). Plant Resources of South-East Asia No 17. Fibre plants Backhuys Publishers, Leiden, Netherlands. 42:399-400.

7. Ojo, M. O. (2019). Impact of Selected Seed Pre-treatment on Emergence and Early Growth of Ceiba patendra (L.) Gaertn. 7(3):7-17. European Journal of Agriculture and Forestry Research. www.eajournals.org.

8. Sarkiyayi, S., Ibrahim, S., \& Abubakar, M. S. (2009). Toxicological studies of Ceiba pentandra Linn. A. J Biochem Res. 3(7):279-281.

9. FAO (Food and Agricultural Organisation). (1968). Food Composition Table for Use in African Food and Agric Organization of the United Nations Rome, Italy. 27: 167- 168.

10. Oladejo, T. A. (2009). Proximate Composition and Micronutrient Potentials of Three Locally Available Wild Fruit in Nigeria. J Agric Res. 4(9):887-892.

11. Behall, K. (1986). Chemistry and function of protein. In: ACS system symposium series, Ed. Fishman, M. L., \& Jen, J. J Am Chem Soc. Washington DC. USA, 310:248-250. 
12. Antia, B. S., Akpan, E. J., Okon, P. A., \& Umoren, I. U. (2006). Nutritive and Antinutritive Evaluation of Sweet Potatoes (Ipomoea batata) leave. Pak J Nutr. 5:166-168.

13. Burkill, H. M. (2000). The useful plants of West Tropical Africa II Bot. Gardens, Kew (k), 1:481-482.

14. Burkill, I. H. (2005). The useful plants of West Tropical Africa families A.D Royal Bot. Garden, 1:691- 692.

15. Friday, E. T., James, O., Olusegun, O., \& Gabriel, A. (2011). Investigations on the Nutritional and Medicinal potentials of Ceiba pentandra leaf: A common vegetable in Nigeria. International Journal of Plant Physiology and Biochemistry, 3, 95-101.

16. Singaravelan, N., \& Marimuthu, G. (2004). Nectar feeding and pollen carrying from Ceiba patendra.

17. Pearson, T. R. H., Burslem, D. F. R., Mullins, P. C. E., \& Dalling, J. W. (2002). Germination Ecology of Neotropical pioneers: Interacting effects of environmental conditions and seed size. Ecology, 83, 2798-2807. http://dx.doi.org/10.1890/00129658(2002)083\%5b2798:GEONPI\%5d2.0.CO;2pentandra by pteropodid bats. Journal of Mammalogy, $\quad$ 85,415-417. http://dx.doi.org/10.1644/15451542(2004)085\%3c0001:NFAPCF\%3e2.0.CO;2

18. Dileep, M., Sudhakara, K., Santosh Kumar, A. V., Nazeema, K. K., \& Ashokan, P. K. (1994). Effect of Seed Size, Rooting Medium and Fertilizers on the Growth of Seedlings of Ceiba pentandra (Linn) Gaertn. Indian Journal of Forestry, 17, 293- 300.

19. Kandya, S. (1990). Studies on the Biochemical basis of Seed Dormancy in Some Forest Tree Species Used in Social Forestry Programmes. Ph.D. Thesis, Dr. H.S. Gour University Sagar, India. 15, 75-76.

20. Orrock, J. L., Levey, D. J., Danielson, B. J., \& Damschen, E. I. (2006). Seed Predation, Not Seed Dispersal, Explains the Landscape-level Abundance of an Early Successional. Plant Journal of Ecology, 94, 838-845. http://dx.doi.org/10.1111/j.1365-2745.2006.01125.x.

21. Otegbeye, G. O., Owonubi, J. J., \& Oviasuyi, P. K. (2001). Interspecific Variation Growth of Eucalyptus growing in Northern Nigeria. Proceedings of Paper Presented at $27^{\text {th }}$ Annual Conference of Forestry Association of Nigeria. 12-16.

22. Robertson, B. I., \& Small, J. G. (1977). Germination of Jubaeopis caffra seeds. Principles, 21: 112-114.

23. Otebgeye, G. O., \& Momodu, A. B. (2002). Preliminary Study of Germination Technique for seeds of Parkia biglobosa. Journal of Agricultural and environment, 3(2); 405-409.

24. Owonubi, J. J., Otegbeye, G. O., \& Nwokedi, C. (2005). Development of pre- germination Technique for Azadirachta indica: Preliminary investigation. Proceedings of papers presented at 30th Annual conference of Forestry Association of Nigeria, held at Kaduna State. Nigeria. 497-503.

25. Ibrahim, A., \& Otegbeye, G. O. (2004). Methods of achieving Optimum germination in Adasonia digitata. Brown Journal of Agriculture, 1(1):53-58.

26. Hall, N., Turnbill, J. W., \& Martensz, P. N. (1981). A Pruinocarpa Tundale Australia Acacia Leaflet, CSIRO Aust. 16:12-20.

27. Marunda, C. T. (1989). Effects of seed pretreatments on the development of Acacia auriculiformis and A. holoserca seedlings. Proceedings of an international workshop held at the Forestry Training Centre, Gympie, Old Australia, 33-36.

28. Tilki, F. (2004). Influence of pre-treatment and desiccation on the germination of Laurrus nobilis L. Seeds. Journal of Environmental Biology, 25(2):1576-161.

29. Alado, M. I., Sodimu, A. I., Momoh, M., Bello, M. I., \& Yahaya, U. F. (2009). The effect of different Treatment on the growth of Flamboyant (Delonix regia). Proceedings of papers presented at International Conference on Global Food Crisis Held at Owerri, Nigeria, 178-181.

30. Ailero, B. L. (2004). Effects of sulphuric acid, mechanical scarification and wet heat mechanical scarification and wet heat treatments on germination of seeds of African locust bean tree, Parkia biglobosa. African Journal of Biotechnology. (3):179-181.

31. Adeola, A. O., \& Dada, A. O. (1985). Potential of Agroforestry plants in Nigeria: Effects of some pre-treatment on seed germination of Acacia albida and Acacia senegals. Research paper (Forest series) No.53 Forestry Research Institute of Nigeria, Ibadan Nigeria. 1-8.

32. Adeola, A. O., \& Dada, A. O. (1986). Pre-treatment effects on seed germination of Acacia nilotica (linn). The Malaysian Forester, 4(49):457.

33. Bradbeer, J. W. (1988). Seed Dormancy and Germination. Published by Blackie and Son Ltd. Glasgow, London. United Kingdom. 40. 